\title{
Associations between ST depression, four year mortality, and in-hospital revascularisation in unselected patients with non-ST elevation acute coronary syndromes
}

\author{
T A Hyde, J K French, C-K Wong, C Edwards, R M L Whitlock, H D White
}

Heart 2003;89:490-495

See end of article for authors' affiliations

Correspondence to: Dr Tom Hyde, Department of Cardiology, The London Chest Hospital, London

E2 9JX, UK;

tom.hyde@

bartsandthelondon.nhs.uk

Accepted

17 December 2002

\begin{abstract}
Objective: To determine the associations between changes on the presenting ECG, in-hospital revascularisation, and four year mortality in patients with non-ST elevation acute coronary syndromes. Design: Prospective evaluation of all consecutive patients admitted in 1993 to the Green Lane Hospital coronary care unit, Auckland, New Zealand. Late follow up was undertaken at a median of 52 months. The ECGs were analysed after the hospital admission.

Setting: Tertiary referral centre with direct local coronary care unit admissions.

Interventions: Patients underwent physician recommended in-hospital revascularisation or initial conservative management.

Results: The four year survival was $88 \%$ in the 115 patients who underwent revascularisation 165 $(19 \%)$ percutaneous and $53(16 \%)$ surgical revascularisation), compared with $75 \%$ in 316 patients managed conservatively $(p=0.024)$. Four year survival for patients undergoing revascularisation versus initial conservative management with respect to ECG groups was: no ECG changes $(n=101)$, $97 \%$ v $92 \%(p=0.35) ;$ T wave inversion or $0.5 \mathrm{~mm} \mathrm{ST}$ depression $(n=108), 89 \% \vee 78 \%(p=0.18)$; ST depression $\geqslant 1 \mathrm{~mm}(n=122), 80 \% \vee 58 \%(p=0.014) ; \chi^{2}=29, p<0.001$ for the linear trend across the groups. On multivariate analysis, independent predictors of four year mortality were: age (odds ratio (OR) 1.05, 95\% confidence interval (CI) 1.01 to 1.08; $p=0.0046$ ); ECG group (OR 1.88, $95 \% \mathrm{Cl} 1.21$ to $2.95 ; p=0.043$ ); radiological pulmonary oedema (OR $2.81,95 \% \mathrm{Cl} 1.18$ to 7.05 ; $\mathrm{p}=0.025)$; and revascularisation (OR $0.43,95 \% \mathrm{Cl} 0.20$ to $0.90 ; \mathrm{p}=0.023$ ).

Conclusions: Among unselected patients with non-ST elevation acute coronary syndromes, in-hospital revascularisation is associated with decreased mortality at up to four years after admission. This association appears greater in patients with ST depression of $\geqslant 1 \mathrm{~mm}$ on the presenting ECG.
\end{abstract}

$\mathrm{P}$ atients with non-ST elevation acute coronary syndromes comprise the majority of those admitted to coronary care units with acute cardiac ischaemic symptoms. ${ }^{1-3}$ Among these patients there is heterogeneity of both risk for future cardiac events ${ }^{4}$ and the benefit of early revascularisation. ${ }^{5-7}$ Presenting ECG changes are predictive of future cardiac events; ST depression in particular is an adverse prognostic marker. ${ }^{8-12}$

Eight randomised trials-TIMI IIIB, VANQWISH $(88 \%$ non-ST segment elevation), MATE, FRISC II, TRUCS, TACTICS, VINO, and RITA $3^{1013-19}$-have compared an invasive strategy (that is, early angiography with appropriate revascularisation) with a conservative strategy (revascularisation guided by recurrent or inducible ischaemia) in patients with non-ST elevation acute coronary syndromes. The recent FRISC II and TACTICS trials have shown a benefit of an early invasive approach in reducing death and myocardial infarction, which occurred mainly among patients with ECG changes or raised blood troponin concentrations. ${ }^{1020}$

To examine the associations between ECG changes at presentation (in particular, ST segment depression), in-hospital revascularisation, and four year mortality, we studied a prospectively identified cohort of patients with non-ST elevation acute coronary syndromes. ${ }^{9}$

\section{METHODS}

\section{Patient population}

All patients admitted to the coronary care unit at Green Lane Hospital, Auckland, New Zealand with chest pain in 1993 were evaluated prospectively. ${ }^{19}$ Of 642 patients with chest pain admitted directly to the coronary care unit, 110 had ST elevation or presumed new left bundle branch block myocardial infarction, 152 had non-cardiac chest pain, and 380 had a non-ST elevation acute coronary syndrome. Of the 380, the 10 were excluded because of missing data or records, ${ }^{9}$ and a further 39 patients were excluded from analysis because their ECGs were unsuitable for ST segment analysis owing to prior left bundle branch block $(n=20)$, paced rhythm $(n=2)$, or missing baseline ECGs $(n=17)$.

As previously described, ${ }^{9}$ the patients were treated with aspirin and usually heparin, and nine were randomised in the PRISM study ${ }^{21}$ to receive intravenous heparin or tirofiban for 48 hours. Medical treatment with $\beta$ blockers, long acting nitrates, and other antianginal agents was given according to the attending physicians' recommendations. Investigations and revascularisation were also done on an individual basis. Creatine kinase (CK) was measured routinely at presentation

\footnotetext{
Abbreviations: $C A B G$, coronary artery bypass graft; $C K$, creatine kinase; FRISC II, Fragmin and fast revascularisation during instability in coronary artery disease; IQR, interquartile range; MATE, medicine $v$ angiography in thrombolytic exclusion trial; OR, odds ratio; PRISM, platelet receptor inhibition in ischaemic syndrome management; RITA, randomised interventional trial of unstable angina; SHOCK, should we emergently revascularise occluded coronaries for cardiogenic shock; TACTICS, comparison of early invasive and conservative strategies in patients with unstable coronary syndromes treated with the glycoprotein Ilb/Illa inhibitor tirofiban; TIMI, thrombolysis in myocardial infarction trial; TRUCS, treatment of refractory unstable angina in geographically isolated areas without cardiac surgery; VANQWISH, VA non-Q-wave infarction strategies in hospital; VINO, value of first day angiography/angioplasty in evolving non-ST elevation myocardial infarction: an open multicentre randomised trial
} 


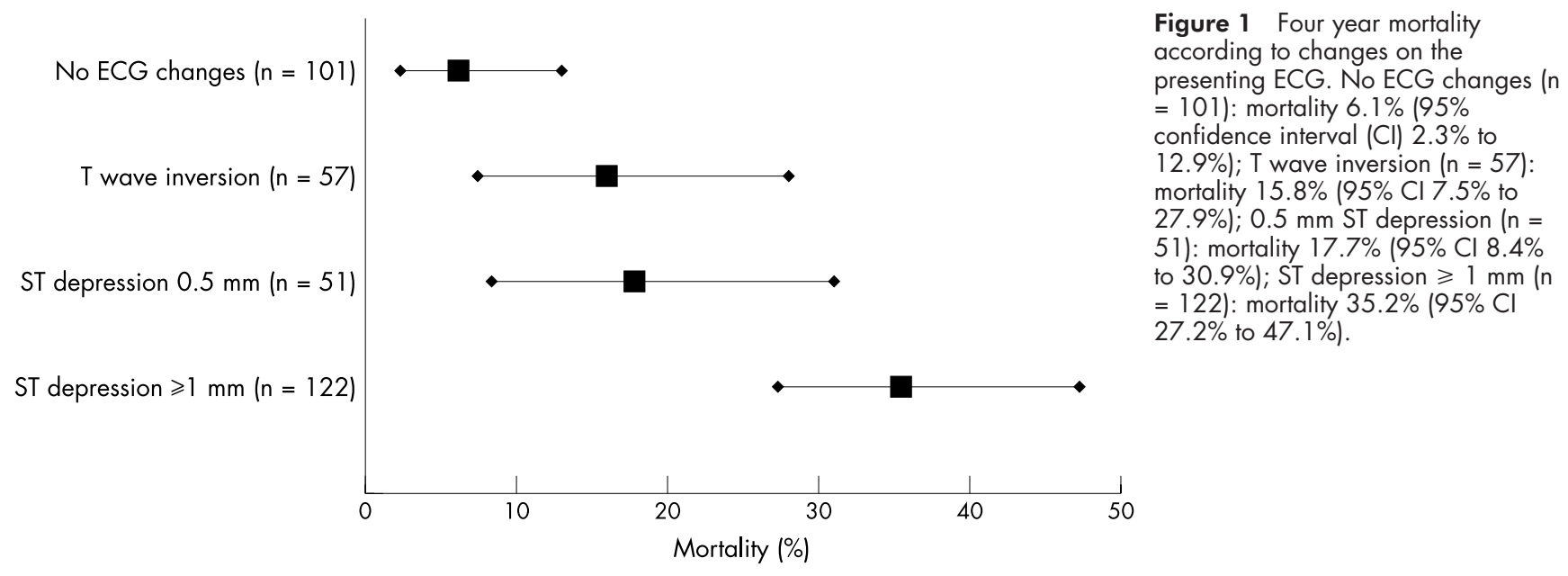

and three times in the next 24 hours; the same schedule was used following further ischaemic episodes. The ECGs recorded at presentation were analysed as previously described. ${ }^{9}$

\section{Clinical definitions}

At presentation, patients were coded according to the Braunwald unstable angina classification. ${ }^{22}$ They were diagnosed as having myocardial infarction at presentation if cardiac enzyme levels exceeded twice the upper limit of the reference range (300 $\mathrm{U} / \mathrm{l}$ ) within 18 hours of admission. Myocardial infarction after presentation was defined by at least two of the following: a history of typical ischaemic pain lasting for at least 30 minutes; elevation of CK to more than twice the upper limit of the reference range; evolving ECG changes or the development of new pathological Q waves. Myocardial infarction following coronary artery bypass grafting was defined as the development of new pathological Q waves in two contiguous ECG leads, or a rise in aspartate transaminase (to $\geqslant 100 \mathrm{U} / \mathrm{ml}$ ), or both. ${ }^{23}$ Myocardial infarction after percutaneous intervention was defined as a new elevation of CK to three times the upper limit of normal, or the appearance of new Q waves.

Early revascularisation was defined as having taken place during the inpatient stay. Readmission with unstable angina was defined as a further hospital admission with ischaemic chest pain without evidence of myocardial infarction. A smoker was defined as a current smoker up to the date of presentation, and an ex-smoker as having ceased smoking for at least one month. Hypertension was defined by treatment being given for hypertension. Diabetes was defined by patient history.

\section{Follow up}

Follow up was performed by telephoning the patients and/or their general practitioners. In addition a National Health Index inquiry was undertaken to identify all readmissions. Current medical treatment and risk factors were determined. Death was classified as cardiac, vascular, or noncardiovascular. Causes of death or readmission were verified by death certificate, hospital or general practitioner records, or the National Health Index.

\section{Statistical analysis}

Categorical variables were compared using the $\chi^{2}$ and Fisher's exact tests (two tailed). Student's two tailed $t$ test was used to compare continuous variables. Survival curves were created using the Kaplan-Meier method and compared using the Mantel-Haenszel statistic. Multivariate analysis was undertaken using stepwise logistic regression in two stages: initially all potential factors were included in the model, the log rank test was used to test the univariate associations, and then factors with a probability value of $p>0.5$ were removed. To examine the association between the changes seen on the presenting ECG, early revascularisation, and late survival, patients were divided into three groups of approximately equal size with low, intermediate, and high four year

Table 1 Baseline characteristics

\begin{tabular}{|c|c|c|c|c|c|c|}
\hline & $\begin{array}{l}\text { No ECG change, } \\
\text { early } \\
\text { revascularisation } \\
(n=34)\end{array}$ & $\begin{array}{l}\text { No ECG } \\
\text { change, early } \\
\text { conservative } \\
(n=67)\end{array}$ & $\begin{array}{l}0.5 \mathrm{~mm} \text { ST } \\
\text { depression/ T wave } \\
\text { inversion, early } \\
\text { revascularisation } \\
(n=45)\end{array}$ & $\begin{array}{l}0.5 \mathrm{~mm} \text { ST } \\
\text { depression/ T wave } \\
\text { inversion, early } \\
\text { conservative }(n=63)\end{array}$ & $\begin{array}{l}\geqslant 1 \mathrm{~mm} \text { ST } \\
\text { depression, early } \\
\text { revascularisation } \\
(n=36)\end{array}$ & $\begin{array}{l}\geqslant 1 \mathrm{~mm} \text { ST } \\
\text { depression, early } \\
\text { conservative } \\
(n=86)\end{array}$ \\
\hline Number & 34 & 67 & 45 & 63 & 36 & 86 \\
\hline Age (years) (mean) & 59.7 & 58.9 & 59.8 & 61.5 & $66.6 \ddagger$ & 69.8 \\
\hline Sex ( $\%$ male $)$ & 82 & 67 & 60 & 51 & 72 & 57 \\
\hline Smoking (\%) (current (ex)) & $15(36)$ & $23(38)$ & $13(44)$ & $23(44)$ & $16(40)$ & $17(37)$ \\
\hline Diabetes $(\%)$ & 8.8 & 9.0 & 13 & 14 & 11 & 19 \\
\hline Hypertension (\%) & 45 & 37 & 38 & 49 & 42 & 46 \\
\hline Previous MI (\%) & $24^{*}$ & 19 & 60 & 58 & 58 & 34 \\
\hline Old $Q$ wave (\%) & 21 * & 18 & 51 & 43 & 39 & 33 \\
\hline Previous CABG (\%) & 15 & 10 & 11 & 14 & 17 & 15 \\
\hline Previous $\mathrm{PCl}(\%)$ & 24 & 13 & 24 & 19 & 8.6 & 2.4 \\
\hline Peak CK (U/I) (mean) & 164 & 254 & 122 & 171 & $162 \dagger \ddagger$ & 402 \\
\hline $\mathrm{Ml}$ at presentation (\%) & 6.1 & 11 & 0 & 3.2 & $2.8 \dagger \ddagger$ & 25 \\
\hline Pulmonary oedema ( $\%$ ) & 0 & 0 & 4.8 & 3.2 & $21 \ddagger$ & 20 \\
\hline
\end{tabular}

$\dagger \mathrm{p}<0.05$, ST depression $\geqslant 1 \mathrm{~mm}$ invasive $v$ conservative

$\ddagger p<0.05$, ST depression $\geqslant 1 \mathrm{~mm} v$ other ECG groups.

${ }^{*} p<0.005$, no ECG change $v$ others.

$\mathrm{CABG}$, coronary artery bypass graft; $\mathrm{CK}$, creatine kinase; conservative, medical management; $\mathrm{Ml}$, myocardial infarction; $\mathrm{PCl}$, percutaneous coronary intervention. 
Table 2 Four year outcomes

\begin{tabular}{|c|c|c|c|c|c|c|}
\hline & $\begin{array}{l}\text { No ECG change, } \\
\text { early } \\
\text { revascularisation } \\
(n=34)\end{array}$ & $\begin{array}{l}\text { No ECG change, } \\
\text { early conservative } \\
(n=67)\end{array}$ & $\begin{array}{l}0.5 \mathrm{~mm} \text { ST } \\
\text { depression/ T wave } \\
\text { inversion, early } \\
\text { revascularisation } \\
(\mathrm{n}=45)\end{array}$ & $\begin{array}{l}0.5 \mathrm{~mm} \mathrm{ST} \\
\text { depression/ T wave } \\
\text { inversion, early } \\
\text { conservative }(n=63)\end{array}$ & $\begin{array}{l}\geqslant 1 \mathrm{~mm} \text { ST } \\
\text { depression, early } \\
\text { revascularisation } \\
(n=36)\end{array}$ & $\begin{array}{l}\geqslant 1 \mathrm{~mm} \mathrm{ST} \\
\text { depression, early } \\
\text { conservative } \\
(\mathrm{n}=86)\end{array}$ \\
\hline \multicolumn{7}{|l|}{ In hospital } \\
\hline Death (\%) & 0 & 0 & 4.4 & 0 & $0 \dagger \ddagger$ & 13 \\
\hline MI (\%) & 2.9 & 0 & 4.4 & 0 & 11.1 & 4.7 \\
\hline Death/MI (\%) & 2.9 & 0 & 6.6 & 0 & 11.1 & 16 \\
\hline \multirow[t]{2}{*}{ Revascularisation } & PTCA $=20$ & 0 & PTCA $=30$ & 0 & PTCA $=15$ & 0 \\
\hline & $C A B G=14$ & & $C A B G=17$ & & $C A B G=22$ & \\
\hline 4 Years & (One patient lost) & (Two patients lost) & & & & \\
\hline Death (\%) & 3.0 & 7.7 & 11 & 21 & 19 & 42 \\
\hline MI (\%) & 9.1 & 11 & 6.7 & 3.2 & 19 & 16 \\
\hline Death/MI (\%) & 9.1 & 17 & 16 & 24 & 31 & 42 \\
\hline Unstable angina (\%) & 52 & 43 & 49 & 57 & $14 \dagger$ & 43 \\
\hline $\begin{array}{l}\text { Death/Ml/unstable } \\
\text { angina (\%) }\end{array}$ & 55 & 48 & 58 & 68 & 42 & 63 \\
\hline Revascularisation * (\%) & 27 & 14 & 29 & 27 & 11 & 24 \\
\hline
\end{tabular}

$\dagger p<0.05$, ST depression $\geqslant 1 \mathrm{~mm}$ invasive $v$ conservative

$\neq \mathrm{p}<0.05$, ST depression $\geqslant 1 \mathrm{~mm}$ v other ECG groups.

*Procedures occurring after index admission.

CABG, coronary artery bypass graft; conservative, medical management; $\mathrm{Ml}$, myocardial infarction; PTCA, percutaneous transluminal coronary angioplasty.

mortality: ST depression $\geqslant 1 \mathrm{~mm}(\mathrm{n}=122)$; no ECG changes $(\mathrm{n}=101)$; and a group combining patients with $\geqslant 0.5 \mathrm{~mm}$ (but $<1 \mathrm{~mm}$ ) ST depression $(\mathrm{n}=5 \mathrm{l})$ (referred to here as "0.5 mm ST depression") or T wave inversion $(\mathrm{n}=57)$ in two or more contiguous leads ( $\mathrm{T}$ wave inversion was $\geqslant 3 \mathrm{~mm}$ in $46 \%$ and $\geqslant 2 \mathrm{~mm}$ in $77 \%$ ) (fig l). The following variables were entered into the final model: age in yearly intervals, ECG group (normal, ST depression $\geqslant 1 \mathrm{~mm}$, or T wave inversion/ST depression $0.5 \mathrm{~mm}$ ), pulmonary oedema, diabetes, previous myocardial infarction, myocardial infarction at presentation, and in-hospital revascularisation.

\section{RESULTS}

Of the 331 patients (mean (SD) age, 62.3 (12) years), 306 $(92 \%)$ were in Braunwald class III, 29 (8.8\%) had radiographic pulmonary oedema, $33(10 \%)$ had myocardial infarction at presentation, 44 (13\%) were diabetic, and 135 (41\%) had a previous history of myocardial infarction (table 1). During the initial hospital stay, 13 patients died $(3.9 \%)$, reinfarction occurred in $13(3.9 \%)$, and the composite end point of death or non-fatal myocardial infarction occurred in $22(6.6 \%)$ (table 2 ).

During the index hospital admission, 129 patients (39\%) underwent coronary arteriography. In-hospital revascularisation procedures were done on 115 patients $(35 \%)$. Sixty five had a percutaneous intervention at a median of 7 (interquartile range (IQR) 4-10) days after admission, one of whom experienced periprocedural infarction; three of these patients also underwent in-hospital coronary artery bypass grafting (CABG). A further 50 patients underwent CABG after a median of 8 (4-13) days, of whom three had periprocedural myocardial infarction (one fatal), and another patient died during CABG.

Among the patients who underwent in-hospital revascularisation, the frequency of three vessel disease was 54\% among patients with ST depression of $\geqslant 1 \mathrm{~mm}$ compared with $31 \%$ among those with $0.5 \mathrm{~mm}$ ST depression or T wave inversion, and $26 \%$ among those with no ECG changes $(p=0.03)$. Of patients undergoing revascularisation procedures, CABG was undertaken in $61 \%$ of those with ST depression of $\geqslant 1 \mathrm{~mm}$, and in $39 \%$ of those in the other two ECG groups $(p=0.03)$.

\section{Four year outcomes}

Vital status was determined at a median of 52 (IQR 48-55) months in $99 \%$ of patients (three were lost to follow up). At follow up, 67 patients had died (20\%), 51 from cardiovascular and 16 from non-cardiovascular causes. Myocardial infarction following the initial hospital admission occurred in 31 patients $(9.3 \%)$ and death or myocardial infarction in 81 (24\%); 140 patients $(42 \%)$ were readmitted to hospital with unstable angina (table 2). Among patients with ST depression of $\geqslant 1 \mathrm{~mm}$, in-hospital revascularisation was associated with a significantly lower incidence of readmission with unstable angina $(43 \% v 14 \% ; \mathrm{p}=0.002)$.

Of the patients managed in an initially conservative fashion, late revascularisation was undertaken in 47 (21\%): 16 had a percutaneous intervention, and 37 had CABG (four patients underwent both procedures); 25 of these procedures occurred following readmission with unstable angina. At follow up the frequency of administration of various medical treatments was as follows: aspirin $89 \%, \beta$ blockers $45 \%$, angiotensin converting enzyme inhibitors $32 \%$, and lipid modifying treatment $48 \%$. There were no significant differences in medical treatment according to revascularisation or changes seen on the presenting ECG.

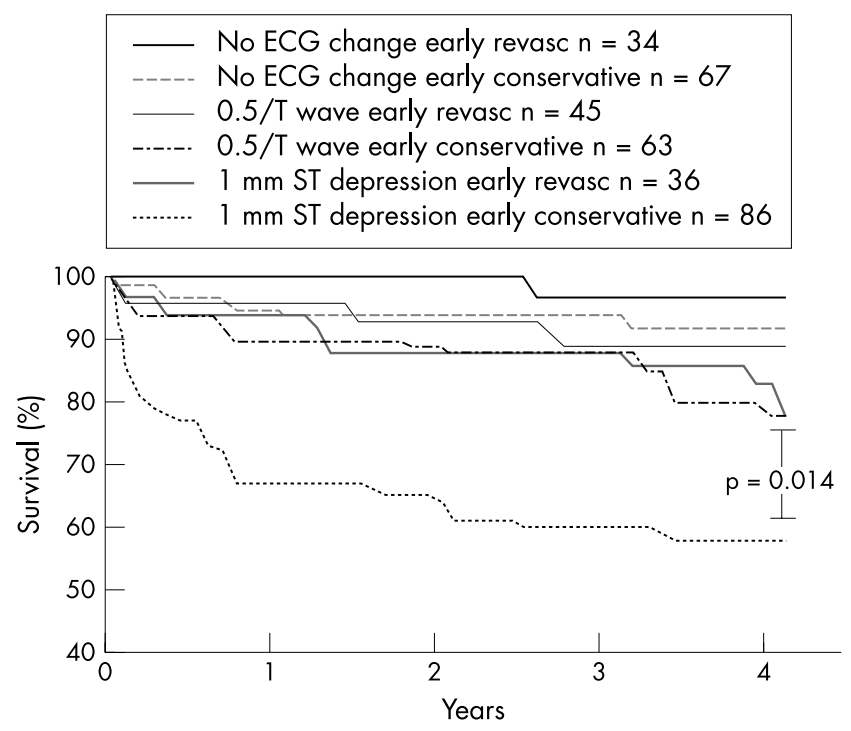

Figure 2 Late survival according to ECG group and treatment strategy: $p>0.05$ for comparisons between revascularisation and initial conservative treatment except for the group with ST depression $\geqslant 1 \mathrm{~mm}$ (as shown). 
Table 3 Associations between early revascularisation and four year mortality among various patient subgroups

\begin{tabular}{|c|c|c|c|c|c|c|c|}
\hline & \multicolumn{3}{|c|}{ Four year mortality by revascularisation } & \multirow[b]{2}{*}{ OR } & \multirow[b]{2}{*}{$95 \% \mathrm{Cl}$} & \multirow[b]{2}{*}{$\chi^{2}$} & \multirow[b]{2}{*}{$\mathrm{p}$ Value } \\
\hline & $\begin{array}{l}\text { Per cent of } \\
\text { patients }\end{array}$ & $\begin{array}{l}\text { Conservative } \\
(\%)\end{array}$ & Revascularisation (\%) & & & & \\
\hline Men & 62 & 27.2 & 11.3 & 0.34 & 0.15 to 0.75 & 7.487 & 0.006 \\
\hline Women & 38 & 22.5 & 11.8 & 0.46 & 0.14 to 1.46 & 1.796 & 0.18 \\
\hline Age $<65$ years & 48 & 11.2 & 1.7 & 0.14 & 0.003 to 0.99 & 4.738 & 0.03 \\
\hline Age $\geqslant 65$ years & 52 & 37.1 & 21.8 & 0.47 & 0.23 to 0.99 & 3.977 & 0.046 \\
\hline Diabetes & 14 & 41.9 & 21.4 & 0.38 & 0.09 to 1.63 & 1.77 & 0.183 \\
\hline No diabetes & 86 & 21.6 & 10 & 0.40 & 0.19 to 0.85 & 5.964 & 0.015 \\
\hline Peak CK $\geqslant 600$ (U/I) & 10 & 36.7 & 50 & 1.73 & 0.10 to 30.3 & 0.142 & 1 \\
\hline Peak CK <600 (U/I) & 90 & 23.9 & 10.9 & 0.39 & 0.20 to 0.78 & 7.417 & 0.006 \\
\hline Pulmonary oedema & 9 & 65 & 33.3 & 0.27 & 0.05 to 1.42 & 1.399 & 0.237 \\
\hline No pulmonary oedema & 91 & 19.4 & 9.1 & 0.42 & 0.19 to 0.90 & 5.119 & 0.024 \\
\hline No previous $Q$ wave & 66 & 21.8 & 7.1 & 0.28 & 0.10 to 0.74 & 7.172 & 0.007 \\
\hline Previous $Q$ wave & 34 & 32.8 & 18.2 & 0.45 & 0.18 to 1.14 & 2.892 & 0.089 \\
\hline Normal ECG & 30 & 7.7 & 3 & 0.37 & 0.04 to 3.34 & 0.215 & 0.643 \\
\hline $\mathrm{T}$ inversion + ST depression $0.5 \mathrm{~mm}$ & 33 & 20.6 & 11.1 & 0.48 & 0.16 to 1.46 & 1.782 & 0.295 \\
\hline ST depression $\geqslant 1 \mathrm{~mm}$ & 37 & 41.9 & 19.4 & 0.34 & 0.13 to 0.85 & 5.587 & 0.018 \\
\hline Total population & 100 & 25.2 & 11.4 & 0.38 & 0.20 to 0.73 & 8.752 & 0.003 \\
\hline
\end{tabular}

$\mathrm{Cl}$, confidence interval; $\mathrm{CK}$, creatine kinase; $\mathrm{OR}$, odds ratio.

\section{ECG changes, late mortality, and benefit of in-hospital revascularisation}

Late mortality was 35\% for patients with ST depression of $\geqslant 1 \mathrm{~mm}, 17 \%$ for patients with $0.5 \mathrm{~mm}$ ST segment depression or $\mathrm{T}$ wave inversion, and $6 \%$ for those with no ECG changes (three way log rank $\mathrm{p}=0.007$ ). Patients undergoing revascularisation had a lower mortality at four years $(12 \% \mathrm{v}$ $25 \%, \log$ rank $\mathrm{p}=0.024$ ). There appeared to be a trend in the four year mortality difference according to initial treatment (revascularisation $v$ conservative) across the ECG groups (fig 1). The associations between in-hospital revascularisation and late mortality among the three groups of patients, which were of approximately equal size, were as follows $\left(\chi^{2}=29\right.$, $\mathrm{p}<0.001$ for the linear trend across the groups) (fig 2):

- for patients with no ECG changes $(\mathrm{n}=101)$ who underwent revascularisation, mortality was 3\% compared with $8 \%$ in those undergoing initial medical treatment $(p=0.35)$

- for patients with ST depression of $0.5 \mathrm{~mm}$ or T wave inversion $(n=108)$, mortality for those undergoing revascularisation was $11 \%$ compared with $21 \%$ for those undergoing initial medical treatment $(\mathrm{p}=0.19)$

- for patients with ST depression of $\geqslant 1 \mathrm{~mm}$ undergoing revascularisation $(\mathrm{n}=122)$, mortality was $19 \%$ compared with $42 \%$ for those undergoing initial medical treatment $(\mathrm{p}=0.014)$.

\section{Predictors of four year mortality}

The four year mortality in the various patient subgroups according to whether or not they underwent revascularisation during their index hospital admission is shown in table 3. Univariate and multivariate predictors of four year mortality are shown in table 4 . Independent predictors of mortality were as follows:

- presenting ECG group: odds ratio (OR) 1.88, 95\% confidence interval (CI) 1.21 to $2.95 ; \mathrm{p}=0.0043$

- age in years: OR $1.05,95 \%$ CI 1.01 to $1.08 ; p=0.0046$

- radiographic pulmonary oedema: OR $2.81,95 \%$ CI 1.18 to 7.05; $\mathrm{p}=0.025$

- in-hospital revascularisation: OR $0.43,95 \%$ CI 0.20 to 0.90 ; $\mathrm{p}=0.024$.

\section{DISCUSSION}

In this study we report that among unselected patients with non-ST elevation acute coronary syndromes, in-hospital revascularisation was an independent predictor of reduced mortality over the four years after admission. Among patients with $\geqslant 1 \mathrm{~mm}$ of ST segment depression, the association between early revascularisation and reduced late mortality appeared to be increased.

The enhanced benefit of early revascularisation observed in patients with ST depression is consistent with subgroup findings from the FRISC II and TACTICS trials, though clinical outcomes after one year have not been reported. ${ }^{10}{ }^{20}$ In the FRISC II study the benefits of early revascularisation in reducing the composite end point of death and myocardial infarction at one year mainly appeared to involve patients with ST depression of $\geqslant 1 \mathrm{~mm}$ (relative risk $0.66,95 \%$ CI 0.59 to 0.88 ), while in patients with no ST depression the relative risk

Table 4 Univariate and multivariate predictors of mortality and survival

\begin{tabular}{|c|c|c|c|c|c|c|c|c|}
\hline \multirow[b]{2}{*}{ Predictors } & \multicolumn{4}{|c|}{ Univariate analysis } & \multicolumn{4}{|c|}{ Multivariate analysis } \\
\hline & $\chi^{2}$ & OR & $95 \% \mathrm{Cl}$ of $\mathrm{OR}$ & $\mathrm{p}$ Value & $\chi^{2}$ & OR & $95 \% \mathrm{Cl}$ of $\mathrm{OR}$ & $\mathrm{p}$ Value \\
\hline Age & 36.534 & 1.08 & 1.05 to 1.12 & $<0.001$ & 8.03 & 1.05 & 1.01 to 1.08 & 0.0046 \\
\hline ECG group* & 28.827 & 4.0 & 2.13 to 7.69 & $<0.001$ & 8.14 & 1.88 & 1.21 to 2.95 & 0.0043 \\
\hline Pulmonary oedema & 26.08 & 6.56 & 2.76 to 15.70 & $<0.001$ & 5.03 & 2.809 & 1.18 to 7.05 & 0.025 \\
\hline In-hospital revascularisation & 8.726 & 0.38 & 0.20 to 0.73 & 0.003 & 5.16 & 0.428 & 0.20 to 0.90 & 0.023 \\
\hline Diabetes & 7.952 & 2.61 & 1.32 to 5.18 & 0.005 & & & & \\
\hline Peak CK $\geqslant 600$ (U/I) & 6.047 & 2.58 & 1.19 to 5.59 & 0.014 & & & & \\
\hline Previous $Q$ wave & 4.483 & 1.80 & 1.04 to 3.12 & 0.034 & & & & \\
\hline
\end{tabular}

* ST depression $\geqslant 1 \mathrm{~mm} v$ other groups.

Non-significant univariate predictors not shown. Male sex: OR 1.10 (95\% Cl 0.63 to 1.91), $\mathrm{p}=0.75 ;$ previous $\mathrm{Ml}$ : OR 1.24 (95\% $\mathrm{Cl} 0.72$ to 2.13 ), $\mathrm{p}=$ 0.442 ; previous aspirin: OR $0.83(95 \% \mathrm{Cl} 0.47$ to 1.46$), p=0.513$.

$\mathrm{Cl}$, confidence interval; $\mathrm{CK}$, creatine kinase; OR, odds ratio. 
was 0.86 (95\% CI 0.61 to 1.20$).^{20}$ In FRISC II, percutaneous revascularisation was undertaken at a median of five days after presentation, and CABG seven days afterwards, and all patients received low molecular weight heparin (dalteparin). In our study, revascularisation also occurred at a median time of one week after hospital admission.

In the TACTICS trial, in which all patients received intravenous unfractionated heparin and tirofiban, and revascularisation was undertaken earlier (median time 25 hours for percutaneous intervention and 89 hours for CABG), 38\% of the patients had ST depression of $\geqslant 0.5 \mathrm{~mm}$ on the presenting ECG. In this group, the composite rate of death, myocardial infarction, and readmission with unstable angina in the conservative arm of the study was $26.3 \%$ at six months, compared with $16.4 \%$ in patients in the invasive strategy group (relative risk $0.62,95 \%$ CI 0.48 to 0.81 ). Patients without ST depression appeared to receive no benefit (15.3\% v 15.6\%). In the TACTICS trial, six month follow up showed that there was a trend towards a worse outcome in low risk patients randomised to an early invasive approach..$^{10}$ In our study there appeared to be a gradient of benefit of in-hospital revascularisation across the ECG groups, with the highest risk patients (those with ST depression $\geqslant 1 \mathrm{~mm}$ ) obtaining the greatest benefit. A retrospective analysis of the TIMI IIIB trial showed that higher risk patients—as judged by a score derived from multivariate predictors of risk, including ST depression—-gained benefit from an early invasive approach, and low risk patients did not appear to benefit. ${ }^{44}$ A possible explanation for the increased benefit associated with early revascularisation seen in patients with ST depression may be that they are more likely to have three vessel coronary disease $\mathrm{e}^{25}$ and are therefore more likely to undergo a prognostically beneficial revascularisation procedure. ${ }^{626}$

Observational studies have also shown that an early invasive approach is associated with improved long term survival. A report of the Olmsted County acute chest pain database found that among 2264 patients with unstable angina, early angiography was associated with improved survival at up to eight years (relative risk $0.63,95 \%$ CI 0.53 to 0.74 ) and that this benefit was greater in higher risk patients. ${ }^{27}$

Our unselected cohort of consecutive patients from one calendar year had a six month mortality of $8.7 \%$, comparable with the figure of $7.6 \%$ reported from a similar patient cohort in the $\mathrm{UK}^{2}$ but higher than the six month mortalities of $3.4 \%$ and $2.4 \%$, respectively, in the FRISC II and TACTICS trials. ${ }^{10} 20$

Of the 53 patients who underwent CABG in our study, two $(3.8 \%)$ died within the subsequent 30 days. In the randomised trials the 30 day mortality following CABG has varied greatly (VANQWISH $8.8 \%$, TACTICS $3.8 \%$, RITA $3.3 \%$, and FRISC II $1.9 \%)$. This may in part reflect differences in the accompanying medical treatment and in the timing of surgery in relation to treatment and recent infarction. In our study there were no periprocedural deaths and only one myocardial infarction associated with percutaneous intervention, although neither cardiac tropin levels nor CK-MB levels were routinely measured. Of note, in the patients with $\mathrm{T}$ wave inversion or $0.5 \mathrm{~mm}$ of ST depression undergoing in-hospital revascularisation, there was an early hazard $(4.4 \%$ death and $4.4 \%$ myocardial infarction in hospital) compared with an initial conservative approach ( $0 \%$ for each), but after one month the mortality was lower in the revascularisation group (fig 2).

In addition to changes on the presenting ECG, patients with acute coronary syndromes without persistent ST elevation can be effectively risk stratified by troponin concentrations. ${ }^{28-31}$ While the TACTICS and FRISC II trials found that patients with raised concentrations of troponin $\mathrm{T}$ were likely to benefit from revascularisation, ${ }^{57}$ we did not measure troponin concentrations routinely.

\section{Limitations}

This was an observational study and the subgroups were defined retrospectively. Randomised studies yield the most appropriate evidence on which to base medical practice, though observational studies can provide valuable insight into clinical effects of treatments. Unappreciated selection biases may have influenced our findings. Patients in this study were enrolled in 1993 before randomised trials ${ }^{1015}{ }^{17}$ provided support for an early invasive approach. Of note, the 13 patients with ST depression of $\geqslant 1 \mathrm{~mm}$ who died in hospital had a median time to death of eight days. We can only speculate about the possible hospital mortality if a different approach to urgent revascularisation had been adopted. As only 57 patients had isolated T wave inversion, the study had insufficient power to evaluate the effects of early revascularisation in these patients.

\section{Conclusions}

Our study suggests that early revascularisation of unselected patients with non-ST elevation acute coronary syndromes appears to be beneficial for at least the first four years, and the benefit may be greater among patients with ST depression of $\geqslant 1 \mathrm{~mm}$ on the presenting ECG. This information may prove useful in the future targeting and timing of revascularisation in patients admitted with non-ST elevation acute coronary syndromes.

\section{ACKNOWLEDGEMENTS}

We gratefully acknowledge the statistical advice of Dr Wanzhen Gao, the secretarial assistance of Ms Charlene Nell, and the editorial assistance of Ms Anna Breckon. The study was supported in part by a grant from the Health Research Council of New Zealand.

\section{Authors' affiliations}

T A Hyde, J K French, C-K Wong, C Edwards, R M L Whitlock, H D White, Cardiology Department, Green Lane Hospital, Auckland, New Zealand

\section{REFERENCES}

1 French JK, Williams BF, Hart HH, et al. Prospective evaluation of eligibility for thrombolytic therapy in acute myocardial infarction. BM 1996;312:1637-41

2 Collinson J, Flather MD, Fox KA, et al. Clinical outcomes, risk stratification and practice patterns of unstable angina and myocardial infarction without ST elevation: prospective registry of acute ischaemic syndromes in the UK (PRAIS-UK). Eur Heart J 2000;21:1450-7.

3 Fox KA, Cokkinos DV, Deckers J, et al. The ENACT study: a pan-European survey of acute coronary syndromes. Eur Heart J 2000:21:1440-9.

4 Antman EM, Cohen M, Bernink PJLM, et al. The TIMI risk score for unstable angina/non-ST elevation MI: a method for prognostication and therapeutic decision making. JAMA 2000;284:835-42.

5 Morrow DA, Cannon CP, Rifai N, et al. Ability of minor elevations of troponins I or $T$ to predict benefit from an early invasive strategy in patients with unstable angina and non-ST elevation myocardial infarction. JAMA $2001 ; 286: 2405-12$

6 Diderholm E, Andre B, Frostfeldt G, et al. ST depression in ECG at entry indicates severe coronary lesions and large benefits of an early invasive treatment strategy in unstable coronary artery disease. The FRISC II ECG substudy. Eur Heart J 2002:23:41-9.

7 Diderholm E, Andrén B, Frostfeldt $G$, et al. The prognostic and therapeutic implications of increased troponin T levels and ST depression in unstable coronary artery disease: the FRISC II invasive troponin T electrocardiogram substudy. Am Heart J 2002;143:760-7.

8 Savonitto S, Ardissino D, Granger CB, et al. Prognostic value of the admission electrocardiogram in acute coronary syndromes. JAMA 1999;281:707-13

9 Hyde TA, French JK, Wong CK, et al. Four-year survival of patients with acute coronary syndromes without ST-segment elevation and prognostic significance of 0.5-mm ST-segment depression. Am J Cardiol 1999;84:379-85.

10 Cannon CP, Weintraub WS, Demopoulos LA, et al. Comparison of early invasive and conservative strategies in patients with unstable coronary syndromes treated with the glycoprotein $\mathrm{llb} / \mathrm{lll}$ a inhibitor tirofiban. N Engl J Med 2001;344:1879-87.

11 Kaul P, Fu Y, Chang WC, et al. Prognostic value of ST segment depression in acute coronary syndromes: insights from PARAGON-A applied to GUSTO-Illb. PARAGON-A and GUSTO Ilb Investigators. Platelet Ilb/Illa antagonism for the reduction of acute global organization network. J Am Coll Cardiol 2001;38:64-71.

12 Nyman I, Areskog M, Areskog NH, et al. Very early risk stratification by electrocardiogram at rest in men with suspected unstable coronary heart disease. The RISC study group. J Intern Med 1993;234:293-301.

13 The TIMI IIIB Investigators. Effects of tissue plasminogen activator and a comparison of early invasive and conservative strategies in unstable 
angina and non-Q-wave myocardial infarction: results of the TIMI IIIB trial. Circulation 1994;89:1545-56.

14 Boden WE, O'Rourke RA, Crawford MH, et al. Outcomes in patients with acute non-Q-wave myocardial infarction randomly assigned to an invasive as compared with a conservative management strategy. $N$ Engl J Med 1998;338:1785-92.

15 FRISC II Investigators. Invasive compared with non-invasive treatment in unstable coronary-artery disease: FRISC II prospective randomised multicentre study. Lancet 1999;354:708-15.

16 McCullough PA, O'Neill WW, Graham M, et al. A prospective randomized trial of triage angiography in acute coronary syndromes ineligible for thrombolytic therapy: results of the medicine versus angiography in thrombolytic exclusion (MATE) trial. J Am Coll Cardiol 1998:32:596-605.

17 Fox K, Poole-Wilson P, Henderson R, et al. Interventional versus conservative treatment for patients with unstable angina or non-ST-elevation myocardial infarction: the British Heart Foundation RITA 3 randomised trial. Lancet 2002;360:743-51.

18 Michalis LK, Stroumbis CS, Pappas K, et al. Treatment of refractory unstable angina in geographically isolated areas without cardiac surgery. Invasive versus conservative strategy (TRUCS study). Eur Heart $J$ 2000:21:1954-9.

19 Spacek R, Widimsky P, Straka Z, et al. Value of first day angiography/angioplasty in evolving non-ST segment elevation myocardial infarction: an open multicenter randomized trial. The VINO study. Eur Heart J 2002;23:230-8.

20 Wallentin L, Lagerqvist $B$, Husted $S$, et al. Outcome at 1 year after an invasive compared with a non-invasive strategy in unstable coronary-artery disease: the FRISC II invasive randomised trial. Lancet 2000;356:9-16

21 PRISM Study Investigators. A comparison of aspirin plus tirofiban with aspirin plus heparin for unstable angina. N Engl J Med 1998;338: 1498-505.
22 Braunwald E. Unstable angina: a classification. Circulation 1989;80:410-14

23 French JK, Scott DS, Whitlock RML, et al. Late outcome after coronary artery bypass grafting in patients aged $<40$ years. Circulation 1995;92 (suppl):11-14-19.

24 Solomon DH, Stone PH, Glynn RJ, et al. Use of risk stratification to identify patients with unstable angina likeliest to benefit from an invasive versus conservative management strategy. J Am Coll Cardiol 2001;38:969-76.

25 Cohen M, Hawkins L, Greenberg S, et al. Usefulness of ST-segment changes in greater than or equal to 2 leads on the emergency room electrocardiogram in either unstable angina pectoris or non-Q-wave myocardial infarction in predicting outcome. Am J Cardiol 1991;67:1368-73.

26 Yusuf S, Zucker D, Peduzzi P, et al. Effect of coronary artery bypass graft surgery on survival: overview of 10-year results from randomised trials by the coronary artery bypass graft surgery trialists collaboration. Lancet 1994;344:563-70.

27 Mathew V, Farkouh ME, Gersh BJ, et al. Early coronary angiography improves long-term survival in unstable angina. Am Heart J $2001 ; 142: 768-74$

28 Hamm CW, Ravkilde J, Gerhardt W, et al. The prognostic value of serum troponin T in unstable angina. N Engl J Med 1992:327:146-50.

29 Stubbs P, Collinson P, Moseley D, et al. Prospective study of the role of cardiac troponin $T$ in patients admitted with unstable angina. $B M$ 1996;313:262-4.

30 Newby LK, Christenson RH, Ohman EM, et al. Value of serial troponin T measures for early and late risk stratification in patients with acute coronary syndromes. Circulation 1998;98:1853-9.

31 Heeschen C, Hamm CW, Goldmann B, et al. Troponin concentrations for stratification of patients with acute coronary syndromes in relation to therapeutic efficacy of tirofiban. Lancet 1999;354:1757-62.

\section{IMAGES IN CARDIOLOGY}

\section{Acquired coronary artery fistula leading to acute myocardial infarction after endomyocardial biopsy}

A 55 year old man with type A aortic dissection underwent an emergency Bentall operation in 1995. Intraoperatively, he developed myocardial infarction. This resulted in progressive heart failure, eventually requiring heart transplantation in January 2002. The transplantation was successful and uncomplicated.

He was admitted for routine endomyocardial biopsy on 11 March 2002. A total of six biopsy fragments were removed and the patient was stable during the procedure. He experienced chest pain two hours later. A 12 lead ECG showed new onset ST segment elevation of $2 \mathrm{~mm}$ over the precordial leads (V2-V4) (upper panel), compatible with a diagnosis of anterior myocardial infarction. A coronary angiogram revealed the presence of a large fistula draining from the distal part of the left anterior descending coronary artery to the right ventricle (lower left panel). No significant stenosis or other abnormalities were observed elsewhere in the coronary system. A PTFE covered stent $3.0 \times 12 \mathrm{~mm}$ (Jostent Coronary Stent Graft, Jomed, Germany) was percutaneously deployed and completely sealed off the fistula (lower right panel).

Cardiac enzymes were raised and peaked at 1549 IU/l (creatine kinase (CK) normal < 103 IU/l), 211 IU/l (CK-MB normal < 24 IU/L), and $4.24 \mathrm{ng} / \mathrm{ml}$ (troponin T). Two dimensional echocardiogram showed a newly developed apical and distal septal hypokinesia. There was no pericardial effusion. In-hospital outcome was uneventful and the patient was discharged two days later.

This case shows that an acute myocardial infarction caused by coronary steal phenomenon resulting from a coronary fistula can be a potentially serious complication during endomyocardial biopsy. Percutaneous implantation of a PTFE covered stent seems an effective treatment.
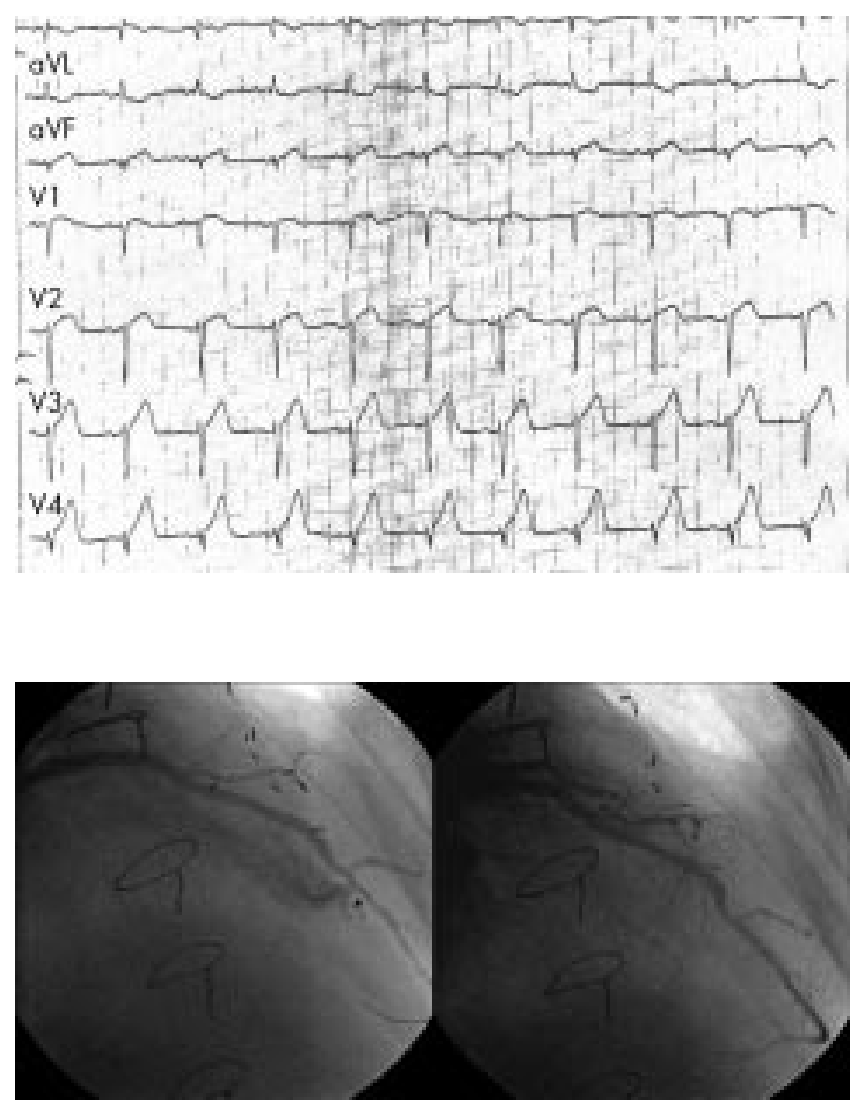